\title{
A Causality Study between both Imports and Taxes and the Informal Manufacturing Entrepreneurs in Egypt (1980-2014)
}

\section{Eman Hassan Ali}

Associate Professor of Economics and Foreign Trade The Faculty of Commerce and Business Administration dremanhassan2010@gmail.com

مستخلص: ينز ايد عدد رواد الاعمال فى القطاع غير الرسمي للصناعات التحويلية فى مصر وفي كثير الإني

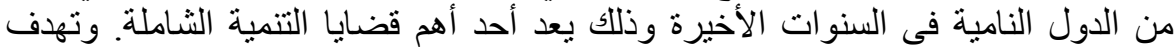

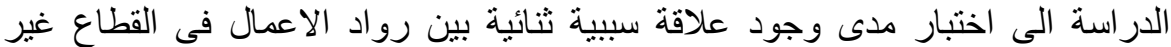

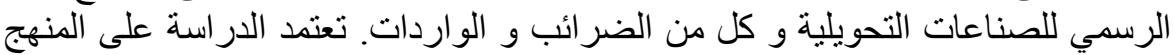

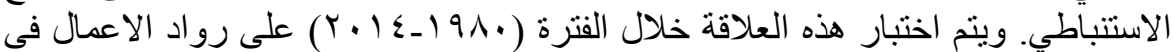

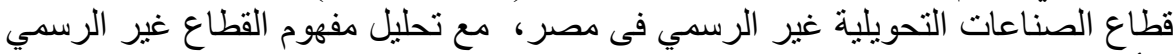

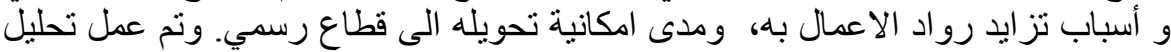

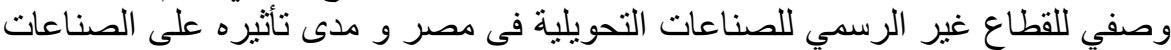

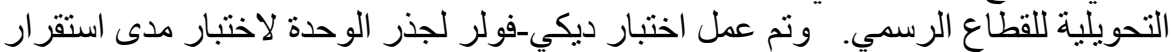

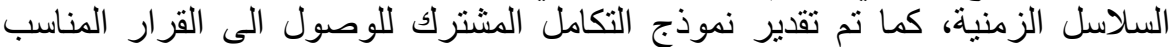

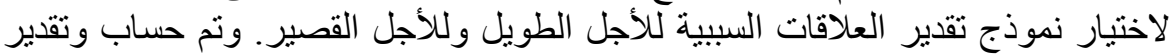

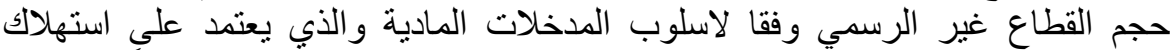

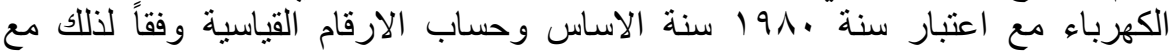

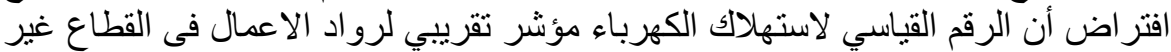

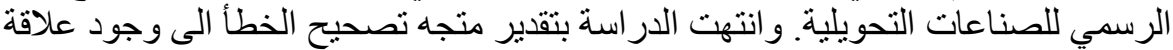

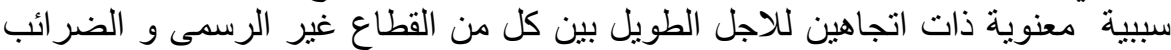

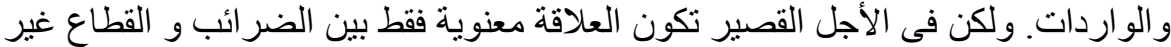

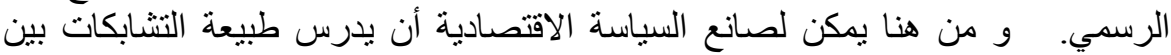

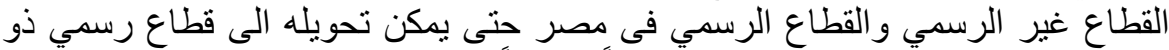

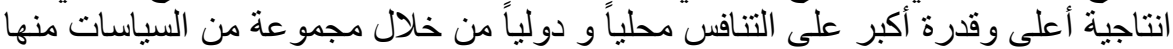

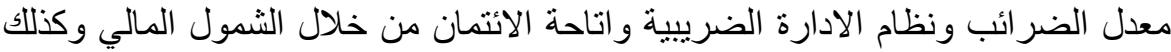
ادارة الواردات للحفاظ على رو اد الاعمال فى القطاع الرسمي.

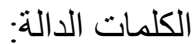

القطاع غير الرسمي، رواد الاعمال، الصناعات التحويلية، العلاقة السببية الثنائية. 


\begin{abstract}
:
The existence and increasing of the informal entrepreneurs in the manufacturing sector is one of the most important issues in the inclusive economic development in Egypt and in the developing countries. The study aims to test the bi-directional causality relationship between the informal manufacturing entrepreneurs and both taxes and imports. The hypothesis is tested for the time period (1980-2014) in Egypt. The methodology of the study depends on the deductive approach. The consumption of electricity is used to calculate the size of the informal manufacturing entrepreneurs as a proxy under two assumptions. The unit root test is applied using (ADF) and the Johansen co integration estimates indicated to use the VECM. The results indicate to the existence of significant long run bi- directional causality relationship between the variables, but in the short run the only significant bi-directional causality relationship exists between informal manufacturing entrepreneurs and taxes. The conclusion of the study is that the policy maker should reform the taxes system, manage imports and support the $\mathrm{CBE}$ initiative for financing the manufacturing small enterprises to formalize the informal manufacturing entrepreneurs.

The Key words;

Informal sector, Entrepreneurs, Manufacturing, Taxes, Imports, VECM.
\end{abstract}




\section{1- Introduction:}

Entrepreneurs are the very important factor for increasing economic growth rates as (Schumpeter and Kirzner) mentioned. The concept of Entrepreneur may need some light, as the considered here is the one who is willing to bear the risk of a new venture if there is a significant chance for profit $^{1}$. The existence of the informal entrepreneurs is one of the most important issues in the inclusive economic development. The informal manufacturing entrepreneurs are a great part of the informal sector in Egypt, in particular, and all over the world, in general. Therefore, in recent years, formalizing the informal entrepreneurship has become one of the main concerns of the Egyptian policy makers. The Egyptian economy faced many domestic and international shocks during the period 2005-2017, such as the completed free trade phases for the textiles and garments industry according to the WTO, the global financial crises and the political instability. Such shocks may have been resulted in increasing the size of informal sector in Egypt.

The concept of informal sector even for the economy or for the entrepreneurship was coined at the beginning of 1970s. There are many theoretical debates about the definition, international statistical comparison and data collecting. Foreign trade, tax evasion, insufficient credit or a stepping stone could be the main determinants of the informal sector in Egypt. The concern here is legal transactions as the illegal transactions is analyzed using the shadow or hidden economy.

\section{The Importance of the study:}

The Informal sector is almost at the top of lists of tax problems in Egypt, and the low revenue efficiency. In

${ }^{1}$ Israel M. Kirzner, (1999). " Creativity and/or Alertness: A Reconsideration of the Schumpeterian Entrepreneur", Review of Austrian Economics, No. 11, pp. 5-17 
2013, the International Labour Organization (ILO) defined formalization of the informal economy as one area of critical importance for sustainable development.

Since the ILO $2^{\text {nd }}$ edition statistical picture mentioned that the informal employment in Egypt is (51\%) which is a significant proportion, the Egyptian policy makers found that they should integrate the informal sector into the mainstream of economic activity ${ }^{2}$. The study concerns about the problem of the distinctive needs of entrepreneurial informal policies to encourage synergistic rather than exploitative the linkages of the informal economy.

\section{The Problem of the study:}

The informal sector in Egypt has increased and may be a source of budget deficit, income inequality and trade deficit, and almost (82) percent of all entrepreneurs in Egypt work in the informal sector in 1996. The main challenge in Egypt for transition to the formal economy is finding the right macroeconomic and noneconomic policy mix that corresponds to the diversity of drivers of informality during the last three decades

\section{The hypothesis:}

This study tries to discuss the following hypothesis "there is a bi-directional relationship (two directions causality relationship) between Informal manufacturing sector entrepreneurs and both of taxes and imports in Egypt.

\section{The Objectives of the study:}

This study has two main objectives, the first: Analyzing the theoretical framework of the informal sector and discussing the case of Egypt, the second: Testing the hypothesis of the study which is mentioned above.

\section{The methodology of the study:}

This study depends on the deductive approach.

${ }^{2}$ ILO, (2013). " Women and men in the informal economy: a statistical picture, $2^{\text {nd }}$ edition, pp. v-1 
The plan of the study is to demonstrate the theoretical framework of informal sector entrepreneurs, analyzing the manufacturing informal entrepreneurs in Egypt, estimating the model and finally the conclusion and policy recommendations.

\section{2- The Theoretical Framework:}

In the recent decades, the relationship between Entrepreneurs and the Informal sector has become increasingly focused in the field of Entrepreneurship studies. The study of (Colin C. Williams and Sara Nadin, 2010) reviews this issue regarding the preponderance of entrepreneurs to engage in the Informal economy, the nature of such Informal Entrepreneurship and the motives ${ }^{3}$. The joint efforts of (ILO) and the Women in Informal Employment: Globalizing and Organizing (WIEGO) was reflected in 2002 in the International Labour Conference (ILC) which has led to a Resolution concerning the informal sector. This resolution has broadened the concept of informality, from enterprises-based notion of the informal sector to informal employment.

The Ukraine's hidden enterprise culture is analyzed to answer the key questions related to the relationship between Entrepreneurs and Informal srctor by (Colin C. Williams and John Round, 2007). They used data from 600 face to face structured interviews, then analyzing the 331 entrepreneurs identified; just $10 \%$ operate on a wholly legitimate basis, while $39 \%$ have licenses to trade and/or have registered their business but conduct a portion of their trade in the Informal economy and $51 \%$ operate as

${ }^{3}$ Colin C. Williams and Sara Nadin , (2010). "Entrepreneurship and the Informal Economy: An Overview", Journal of Developmental Entrepreneurship, Vol. 15, No. 4, pp. 361-378.

- Mai Thi Thanh Thai and Ekaterina Turkina, (2014). "Macro-level determinants of formal entrepreneurship versus informal entrepreneurship", Journal of Business Venturing, Vol. 29, Issue 4, July, pp. 490-510. 
unregistered enterprises and conduct all of their trade on an off-the-book basis ${ }^{4}$.

This part of the study tries to analyze the concepts and theories, the determinants and the effects of the informal sector.

\section{2/1 The concept of Informality:}

It is important to understand the nature and drivers of informality as its economic and social consequences are wide ranging. (D. Andrews, A.C. Sanchez and Asa Johansson, 2011) critically reviewed the current state of cross-country research on informality and discussed how existing data sources can be more effectively employed and extended to shed light on the link between public policies and Informality ${ }^{5}$. The concept of the Informal Economy in the recent study is the fiscal one which is related to the work of (Feige 1989), (Tanzi 1983) and (Rogoff 2002), as they were interested in the small entrepreneurs operations for making money without paying any taxes ${ }^{6}$.

The concept of unregistered economy which does not pay any remittances of tax for the government has many terms and theoretical debates; Informal, shadow, underground, unobserved, hidden, unreported, dual or even the second economy, those are some terms used to describe the enterprises that do not have a license by the government and don't pay taxes.

Before the 1970s the work of (Boeke 1953), (Greetz 1963) and (Lewis 1954) paved the way of dualistic approaches which offered an extraordinary space for expansion to the new theories of economic development and the

${ }^{4}$ Colin C. Williams and John Round, (2007). "Entrepreneurship and the Informal economy: A study of Ukraine's Hidden enterprise culture", Journal of Developmental Entrepreneurship, Vol. 12, No. 1, pp. 119-136.

${ }^{5}$ D. Andrews, Aida Caldera Sanchez and Asa Johansson, (2011). "Towards a Better Understanding of the Informal Economy", OECD Economics Department Working Papers, No. 873, OECD Publishing, Paris, pp. 2.

${ }^{6}$ G. Abdel Gawad, (2003). "Measuring the macro economic e ects of the hidden economy in Egypt", Unpublished Doctoral Dissertation, Helwan University, Egypt. 
measurement of GDP to include all sectors of economic activities $^{7}$.

The Neo-classical growth theory has concerned with one sector models, but most developing countries contain within them multiple economies operating in distinctly different manners and different levels of productivity. After (Lewis, 1954) brought the concept of dual economies into focus, more recently (Banerjee and Duflo,2005) and (Temple,2005) have suggested that a better understanding of growth and development requires the explicit adaption of models that incorporate heterogeneity within economies. The study of (Dietrich Vollrath, 2009) analyzed the dual economy in long run development, He provides a model of the dual economy in which the productivity differences arise endogenously, and the model demonstrates how a dual economy will originate, persist and eventually disappear within a unified growth framework ${ }^{8}$. The informal sector as a dualism of the economy needs growth models suitable for this issue, the study of (Jonathan Temple and Ludger Wößmann, 2006) developed empirical growth models suitable for dual economies and studied the relationship between structural change and economic growth. After cross-country growth regressions, the estimates of the models implied sizable marginal product differentials, and indicated that the reallocation of labour makes a significant contribution to the international variation in productivity growth ${ }^{9}$.

7 - Jacques Charmes, (2012). " The Informal Economy Worldwide: Trends and Characteristics", the journal of applied economic research, vol. 6, no.2,pp. 103132

- Martha Alter Chen, (2012). "The Informal Economy: De nitions, Theories and Policies", WIEGO Working Paper $\mathrm{N}^{\circ} 1$, August.

${ }^{8}$ Dietrich Vollrath, (2009). "The dual economy in long-run development", Journal of Economic Growth, No. 14, pp. 287-312.

9 Jonathan Temple and Ludger Wößmann, (2006). "Dualism and cross-country growth regressions", Journal of Economic Growth, No. 11, pp. 187-228. 
The term "Informal sector" was introduced by the British anthropologist (Keith Hart, 1971) when he was studying the economic activities in Ghana, and the second use of this term was in 1972 when ILO used it in the official report instead of using the term "Traditional sector". This sector relates to poor working conditions, absence of social security, low productivity and low safety and health standards.

The term informal economy may be has expanded to include not only the unreported income from the production of legal goods and services or unregistered small scaled economic activities, but also the illegal economic activities. The first type is called the "Grey economy" and the second" the Black economy". In this manner this study concerns with the informal economy in which legal goods and services are traded but not included in national accounts.

The informal sector was defined by ICLS referring to the characteristics of the economic units in which the persons work: non registration, size under five permanent paid employees and to some extent legal status. The operative definition of informal sector in Egypt is that; Firms are considered informal if they don't have an operating license or if they are not registered in the commercial registry ${ }^{10}$.

This phenomenon is a fact of life around the world, and it is interesting by its nature. Because the informal entrepreneurs exist but it is difficult to be measured, it may be difficult to get the correct information about their extent and impact on the goods and labor markets. The informal economy may be linked to the domestic formal economy through the domestic supply chain or linked to the international economy through the Global Value Chains. There may be mapping formal-informal linkages, and these

${ }^{10}$ Ahmed Galal, (2005). " The Case for Formalization of Business in Egypt", Policy Viewpoint, ECES, the Egyptian Center for Economic Studies, September, p. 2. 
linkages may be mechanisms of institutional design (coproduction of public services, bottom of the pyramid approaches). This case corresponds with governance implications and politics of Formal-Informal Linkages. The formal-informal linkages can improve but also worsen the distribution of costs and benefits ${ }^{11}$. Although the significance of informal sector has varied in different periods and across different countries and has been analyzed as a social phenomenon, this issue has been neglected as an economic phenomenon so, it deserves a greater understanding of entrepreneurship and strategy in the informal economy with a special focus on the public choice (analysis) approach ${ }^{12}$.

2/2 The size of the Informal sector: A large burden of taxation and security contributions combined with government regulations are the main determinants of the size of the informal economy ${ }^{13}$. Some studies use the monetary method "the currency approach" which is based on econometric estimates of the demand for money, to measure the size of the shadow economy when they assume that informal economy is equal to the shadow economy ${ }^{14}$. The electricity consumption (the unit elasticity scenario) is more suitable for estimating the size of the informal manufacturing enterprises (entrepreneurs) in the recent study.

${ }^{11}$ Kate Meagher, (2013). "Unlocking the Informal Economy: A literature review on linkages between formal and informal economies in developing countries", WIEGO working paper No 27, April.

12 J.W.Webb, R.D.Ireland and D.J.Ketchen,JR, (2014)." Toward a greater understanding of Entrepreneurship and strategy in the informal Economy", Strategic Entrepreneurship Journal, 8,pp 1-5.

- Klarita Gërxhani, (2004). " The informal sector in developed and less developed countries: A literature survey", Public choice, 120, pp. 267-300.

${ }^{13}$ Friedrich Schneider, (2002). "Size and Measurement of the Informal Economy in 110 countries around the world, Australian National Tax Centre and World Bank.

${ }^{14}$ Hildegart Ahumada, Facundo Alvaredo and Alfredo Canavese, (2007). "The Monetary Method and the Size of Shadow Economy: A Critical Assessment", Review of Income and Wealth, Series 53, Number 2, June. 


\section{2/3 The determinants of the Informal Sector growth:}

After demonstrating the concepts and the definition, the study tries to analyze the main determinants of informality of economic activities as mentioned in economic theory and the previous studies. Why have the informal entrepreneurs continued to expand and grow? There is no simple answer to this question, even though the existence of some competing theories about the causes of Informality. The exclusion model, the rational exit model and the dual economy are the most common explanations of firm's behavior in the informal sector. The study of (Carr and Chen, 2001) analyzed the mix of sets of factors that would explain the persistence or expansion of the informal economy in most countries or industries. The first set of factors relates to the pattern of economic growth, as some countries have pursued capital-intensive growth "jobless growth". Many frustrated formal job seekers created their own work in the informal economy. Another pattern of economic growth "high tech growth" tends to create more high skill service sector jobs than lower skill manufacturing jobs.

The second set of factors has to do with economic restructuring and economic crisis, as due to economic reforms or economic crises the informal sector tends to expand, when public enterprises are closed or public sector is downsized, households need to supplement formal sector earnings with informal incomes especially in response to inflation. The third set of factors relates to the global trade and investment patterns, as to increase their global competitiveness, investors often move to countries that have low labour cost or shift to informal employment arrangements. Furthermore, there has been a growing attitude towards the Regional Value Chains (RVCs) or the Global Value Chains (GVCs) and Outsourcing, and the privilege of large companies and the disadvantages of small 
and micro entrepreneurs who face a lot of difficulties with globalization $^{15}$.

The present study is concerned with the analysis of three main factors (or determinants) as causes of informal entrepreneurs and results of their increasing as follow:

\section{1) Tax Evasion:}

An important determinant of Informality in a country is its tax enforcement capacity. (Ordònez, 2014) assess the quantitative effect of incomplete tax enforcement on aggregate output and productivity using a dynamic general equilibrium framework for Mexico. He investigates the effects of improving tax enforcement and showed how the distortions in tax system affect the economy in three ways; by reducing the capital-labour ratios of informal enterprises; by misallocating resources towards lowproductive establishments and by allowing low-productive entrepreneurs to enter ${ }^{16}$.

Tax evasion is assumed to be the most important cause of informality as the informal entrepreneurs must have concluded that the net benefits from operating under the formal rules of the game are less than the net benefits of staying informal, but when the ethics is considered is there a difference in analysis? Tax evasion is a worldwide phenomenon and may be an acute problem especially in developing countries. The human beliefs and values are examined by ( McGee and Michael Tyler, 2006). They found that less educated people are more opposed to tax evasion than better educated people; and poorer people are more opposed to tax evasion than wealthier people,

\footnotetext{
${ }^{15}$ Marilyn Carr and Martha Alter Chen, (2001). "Globalization and the Informal Economy: How Global Trade and Investment Impact on the working poor",WIEGO, Women in Informal Employment Globalizing and Organizing, pp. 1-2 ${ }^{16}$ Jolio Cesarleal Ordòňez, (2014). "Tax collection, the informal sector, and productivity", Review of Economic Dynamics, Vol. 17, Issue 2, April, pp. 262-286.
} 
according to a study of 33 countries $^{17}$. Tax policy everywhere is shaped by changing economic conditions, technological possibilities and the political institutions and the relationship between tax policy and informality is considered a very important issue in developed and developing countries, and that may be before the IMF (2013) cited "low revenue efficiency in Greece" is partly a result of their large Informal Economy. It may be believed that formalization is merely an effort to raise funds for the Treasury with little benefits to the entrepreneurs and the workers all over the world. If the tax system reforms need to be evaluated to cure the tax obstacles to informal entrepreneurs and tax evasions there is a need for reforms targeting small entrepreneurs ${ }^{18}$.

To some extent, there is also a need to analyze the two ways relation between taxes and informality. There is a negative impact of the informal manufacturing entrepreneurs on the treasury because of the tax evasion and revenue loss, and this issue was examined and analyzed by (Peacock \& Show 1982), (Ricketts 1984), (Lai \& Chang 1988), (Zameck 1989) and (Bhattacharya 1994).

\section{2) Credit availability:}

Access to finance is one of the biggest obstacles for manufacturing enterprises in developing countries, so the World Bank produces a country profile for a lot of developing countries though Enterprise surveys to focus on many aspects of the business environment. Financial development has been shown to be associated with faster and improved allocation efficiency. More recently, studies have emphasized the critical role played by informal

\footnotetext{
${ }^{17}$ Robert W. McGee and Michael Tyler, (2006). "Tax evasion and Ethics: a Demographic study of 33 countries", Andreas School of Business Working paper, Barry University, USA.

18 Somaia A.A. Abdel-Mowla, (2012). " The Egyptian tax system reforms, investment and tax evasion (2004-2008)", Journal of Economic Administrative Science, Vol. 28, No. 1, pp. 53-78.
} 
networks and financial channels even in developed markets. Focusing on micro-finance and the informal economy, ILO studied the unrecorded remittances which have become one of the most critical dimensions of domestic consumption, investment and foreign trade transactions ${ }^{19}$. Formal and Informal finance is an important issue in developing countries economic growth. The Ayyagari, A.Demirgüç-Kunt and V. Maksmovic, 2008 study takes a closer look at firm financing patterns and China's economic growth using a database of 2400 Chinese firms. They found that relatively small percentage of firms in the sample utilizes formal bank finance with a much greater reliance on informal sources. However, the results suggest that financing from the formal financial system is associated with faster firm growth ${ }^{20}$.

A large literature evaluates the effect of credit market frictions on entrepreneurship (Blanch flower and Oswald 1998), (Paulson and Townsend 2004) and (Buera 2008). The impact of taxation and credit constraints on the informal economy has been analyzed by the Evans and Jovanovich (1989) using an entrepreneurship model. This model has been extended by J.P. Araujo and M. Rodrigues (2016) to analyze the operation of entrepreneurs either in the formal sector - in which they have limited access to credit markets and must pay taxes - or in the informal sector - in which they can avoid paying taxes, but have no access to credit markets. They calibrated the model for the Brazilian economy and evaluated the impact of credit frictions and taxation on occupational choices, aggregate

19 Shivani Puri and Tineke Ritzema, (2001). " Migrant Worker Remittances, Micronance and the Informal Economy: Prospects and Issues", Working Paper No.21, International Labour Office, International Labour Organization, Enterprise and Cooperative Development Department, Social Finance Unit.

${ }^{20}$ Meghana Ayyagari, Asli Demirgüç-Kunt and Vojislav Maksmovic, (2008). Formal versus Informal Finance: Evidence from China", Policy Research Working paper, WPS4465, The World Bank. 
output and inequality. The results of their study refer to that; removing all distortions can improve aggregate efficiency, because this induces entrepreneurs to switch to the formal sector and the superior technology. Most of this effect comes from removing credit market frictions ${ }^{21}$.

The credit scarcity in developing countries was analyzed also using Brazilian manufacturing firm-level data by (A.M.H.P. Ambrozio, F.L. de Sousa, J.P.M. Faleiros and A.A. Sant'Anna, 2017) ${ }^{22}$. Their results show that even small and middle firms are not credit constrained when listed in the stock market or when the exports sales is higher.

\section{3) Imports:}

The impact of Globalization and trade liberalization on informal economy is a main concern for UNCTAD, ILO, WTO and WIEGO, but the relationship between trade liberalization and informal activity has not received the attention it may deserve, whether theoretical or empirical. The Global trade and investment patterns are having a dramatic impact on employment and work arrangements around the world. This impact can be both negative and positive and differs by industry, employment status and trade, as some entrepreneurs in the informal economy have been able to find new opportunities and new markets for their products while others have lost everything.

It was generally believed during 1960's and 1970's that, with economic growth, the informal economy would shrink. However, many jobs in developing countries remain in the informal economy, despite the massive increase in international trade.

\footnotetext{
${ }^{21}$ Julia P. Araujo and Mauro Rodrigues, (2016). "Taxation, credit constrains and the informal economy", Economia, 17, pp. 43-55.

${ }^{22}$ Antonio Marcos Hoelz Pinto Ambrozio, Filip Lage de Sousa, Joao Paulo Martin Faleiros and Andre Albuquerque Sant' Anna, (2017). " Credit scarcity in developing countries: An empirical investigation using Brazilial firm-level data", EconomiA, 18, ELSEVIER, pp. 73-87.
} 
The study of Marco Fugazza and Norbert Fiess, (2010) analyzed the relationship between trade liberalization and informality; they used three different data sets to assess the sign of the relationship. Their empirical results provide a mixture picture, the macro-founded data tend to produce results supporting the conventional view (posits that trade liberalization would cause a rise in informality), while the micro-founded data do not. Empirical results also suggest that while informal output increases with deeper trade liberalization, informal employment falls ${ }^{23}$.

The study of Marc Bacchetta, Ekkehard Ernst and Juana P.Bustamante (2009) has analyzed the key facts on globalization, trade and informal employment, the varieties of informality, openness to trade and informality, then, the impact of informality on trade and growth (How does informality shape macroeconomic performance?), informality and business cycles, capital flows and informality,(Does informal employment lock countries into trade patterns?), finally, the study discussed the robust policies for formalization of firms and supporting transitions from informal jobs to formal employment ${ }^{24}$.

The study of Ravi Ratnayake, (2016) has also discussed the role of trade in fostering the formal sector and inclusive growth in Asia-Pacific; $\mathrm{He}$ argues that a range of complementary policies needs to be deployed alongside a managed opening of national economies. Effective complementary policies likely to raise the inclusivity of growth include increasing labour market flexibility, rising aggregate investment, lifting expenditure on information

\footnotetext{
${ }^{23}$ Marco Fugazza and Norbert Fiess, (2010). "Trade Liberalization and Informality: New stylized Facts", Policy Issues in International Trade and Commodities, Study series No. 43, UNCTAD.

${ }^{24}$ Marc Bacchetta, Ekkehard Ernst and Juana P.Bustamante, (2009). "Globalization and Informal Jobs in Developing Countries", WTO and ILO, Sep, 15.

- Anushree Sinba, (2011). "Trade and the Informal Economy", Trade and Employment: From Myths to Facts, Editors: Marion Jansen, Ralf Peters and Jose Manuel Salazer-Xirinachs, ILO and EU.
} 
and communications technologies and improving access to education $^{25}$.

Trade usually improves growth outcomes by rising productivity in the traded goods sector but, at the same time, lowering productivity in the non-traded goods sector. One of the reasons is that the transition to openness involves a change in the structure of demand for labour, frequently increasing the demand for skilled labour while reducing the demand for unskilled labour ( the informal sector).

This issue was discussed by (Bill Gibson, 2012) using a multi- agent model of the Informal sector. His analytical model was first developed to explore the possible range of relationship between formal and informal employment. Data from the agent-based model support protecting formal sector jobs with current account restrictions. It is seen that restrictions on outsourcing can have a positive effect on formal sector activity. When off shoring restrictions are also considered, it is seen that formal sector employment growth is less robust. Finally, unrestricted current and capital account activity produces a steady state with near zero informal activity, while restrictions preserve the informal sector indefinitely ${ }^{26}$.

The structure of imports and the nature of involving in the Regional Value Chains (RVCs) or the Global Value Chains (GVCs) determines the positive or negative impacts of imports on the firms exit from the home market, the increasing of informality as an alternative for job opportunities and employment.

The issue of trade reforms, Informal sector activity and employment was discussed for Nigeria in the joint WTO-

\footnotetext{
${ }^{25}$ Ravi Ratnayake, (2016). " The role of trade in fostering Inclusive Growth in AsiaPacific", in, Managing Globalization in the Asian Century, Editors; Hal Hill and Jayant Menon, ISEAS Publishing, Singapore.

${ }^{26}$ Bill Gibson, (2012). "Trade, Employment and the Informal sector: An agent-base analysis", The Journal of Applied Economic Research, No.6, pp. 277-310.
} 
ILO workshop on Global Trade and Employment in 200927. Also in India this issue was analyzed as Globalization and economic reforms affect the formal and informal sectors, (E. Siggel, 2010) mentioned that the traditional model used to explain the impact of these forces was labour market segmentation and migration. Meanwhile, workers laid off in the formal sector increase informal labour supply, leading to wage decline and increased poverty. He examined the impact of India's economic reforms in 1990's and has found a more appropriate model driven by expansion both in labour supply and in demand, through outsourcing, skill transfer and new enterprises ${ }^{28}$.

\section{3- The Formalization of the Informal Economy:}

There are many winners and losers from the formalization of the Informal manufacturing entrepreneurs. In June 2015, the ILC adapted the transition from the informal to the formal economy recommendation (No.204), the first international labour standard which focuses on the informal economy in its entirety ${ }^{29}$.

The ILO helped many developing countries, especially in South Asia, for facilitating the formalization of the informal economy using programs with a strategy and many phases during June 2012- December 2016 and the donor was the Govt. of Japan ${ }^{30}$. The ILO strategy and programs use the Local Economic Development (LED)

\footnotetext{
${ }^{27}$ Sam O. Olo $\mathrm{n}$ and Abiodun O. Folawewo, (2009). "Trade Reforms, Informal Sector Activity and Employment", A research discussion paper, joint WTO-ILO Workshop on Global Trade and Employment, 31 August-1 September 2009, Geneva, Switzerland.

${ }^{28}$ Eckhard Siggel, (2010). "The Indian informal sector: the impact of globalization and reform", International Labour Review, Vol. 149, No. 1, International Labour Organization.

${ }^{29}$ ILO, (2018). " Women and men in the Informal Economy: a statistical picture, $3^{\text {rd }}$ edition, pp. v-1

${ }^{30}$ ILO, (2017). "Way out of Informality: Facilitating Formalization of the Informal Economy in South Asia.
} 
approach, aimed at engaging the micro and small enterprises and promote social protection. Reducing Informality is often seen as a central objective of tax reform in developing countries, so thinking in terms of reducing informality may be a useful guide for making the tax policy $^{31}$.

The informal-formal sector linkages should be analyzed to decide the best way of intervention in the informal sector in developing countries. ( $\mathrm{Rad}$ and M. Willumsen, 2010) studied the economic reforms and the informal sector in developing countries and analyzed the informal-formal linkages. Within a general equilibrium framework of a developing economy with a foreign owned factor of production. Although, they found that the informal-formal relationship is pro-cyclical. Nevertheless, it calls for into question the conventional wisdom on the benefits of intervention in the informal sector of developing countries, particularly where multinational corporations subcontracted labour-intensive stages of production to the informal sector ${ }^{32}$.

\section{4- The informal Manufacturing Entrepreneurs in Egypt}

Discovering the motives of people to engage in informal economic activities and exploring their nature are more important than measuring their size.

According to (Schneider,1998) estimates using electricity approach, the informal sector in Egypt accounts for nearly $(68 \%)$ of the GDP in 1998, while his estimates for Egypt in 2000 using the currency demand approach was near to

\footnotetext{
${ }^{31}$ Ravi Kanbur and Michael Keen, (2015). "Reducing Informality", Finance and Development, the IMF, March, pp. 52-54.

32 Hassan Arvin-Rad and Maria Willumsen, (2010). " Economic Reform, informalformal sector linkages and intervention in the informal sector in developing countries: A paradox", International Review of Economics and Finance, Vol. 19, Issue 4, October, pp. 662-670.
} 
(35.1\%) of GDP. The percentage was changed in 2009 when the latent variable approach was used and accounts for $(36.5 \%)$. In 2000, the Informal Economy in Egypt (current USD in billion) was (3498) and the Informal Economy GNP per capita was $(523)^{33}$.

To analyze the change here, it is important to distinguish between the different approaches and the exact definition of informal entrepreneurs which is concerned here. Formalization the manufacturing entrepreneurs in Egypt require detailed firm-level information about the cost and benefit associated with entry, operation and exit in both the formal and informal sector.

Formalization with reform would increase the private value of the after tax profit for firms and this may be close to 23 percent. Formalization in Egypt would increase GDP by 1.3 percent every year; Entrepreneurs would gain 1.0 percent of GDP and workers 0.7 percent of GDP. In addition, because of the productivity improvement the treasury would gain 1.3 percent of GDP, as profit increase, but consumers may be the only group that is expected to be worse off by 1.7 percent of GDP, because they have to pay value-added $\operatorname{tax}^{34}$. Even though, the study concerns about manufacturing entrepreneurs they are only one group among many winners of formalization. Workers, consumers and government are the other main groups affected by formalization.

${ }^{33}$ F. Schneider, Op.cit, p.6

${ }^{34}$ Ahmed Galal,(2005), Op.cit 


\section{4/1 The analysis of the Manufacturing industries}

\section{Entrepreneurs in Egypt ${ }^{35}$ :}

The objective is to focus on many aspects of business environment to encourage firms to operate efficiently, formalizing the informal sector and strengthen incentives for firms to innovate and to increase productivity. A more formal productive private sector expands employment and taxes contributions necessary for public investment in health, education and infrastructure. The main points for the analysis are firms characteristics, international trade, access to finance, informality, regulations, permits and taxes.

The analysis for the manufacturing informal sector, depends on the top subgroup sectors, which includes data for: 1-all manufacturing, 2-food, 3- textile,4- garments, 5leather products, 6- printing \&publishing, 7- chemicals and chemical products, 8- rubber \& plastics products, 9- nonmetallic mineral products, 10- fabricated metal products, 11- furniture, 12- wood products and 13- other manufacturing.

The practices of the informal sector are defined as one of the biggest obstacles in Egypt in 2016 by a percent of (3.1) for all firms, the percent was (3.7) for small firms, (1.8) for medium and (2.6) for large firms ${ }^{36}$. The following indicators are the main aspects for the analysis of the linkages between formal- informal manufacturing entrepreneurs, and the following percents are computed for the manufacturing sector only in Egypt by the World Bank in two distinguished surveys:

35 This analysis depends on two surveys of the World Bank, the rst was in 2013 and the second was in 2016, as it is di cult for the recent study to make a survey for the manufacturing entrepreneurs in Egypt. The World Bank Enterprise Survey depended on 1827 rms and they were interviewed between October 2016 and May 2017.

${ }^{36}$ The size of the $r m s$ is determined by the number of employees; $(5-19)=$ small, $(20-99)=$ medium and $(100)$ or more $=$ large . 
1) The percent of firms competing against unregistered or informal firms in Egypt: in 2013 it was (54.3\%) for all countries, $(39.6 \%)$ for the Middle East \& North Africa, and $(47.9 \%)$ for Egypt. This percent was decreased in 2016 survey for Egypt to be ((43.0\%), the following graph demonstrates the manufacturing entrepreneurs behavior with informality:

Graph (1): The percent of firms competing against Unregistered or informal firms c

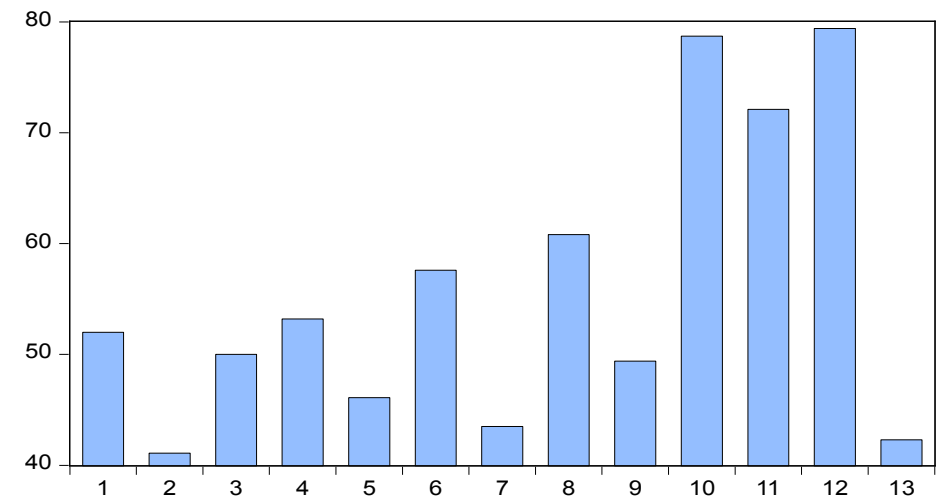

The source: the graph is done using Eviws 8 and the data of the World Bank survey 2013.

The percent for small firms was (49.6), the percent for medium firms was (31.8) and the percent for large firms was (28.2) in 2016. According to the graph the highest percent was for (the industry No. 12) wood products (79.4) and then (the industry No. 10) fabricated metal products industry (78.7) and the least percent was for firms in (the $2^{\text {nd }}$ column) food industry.

2) The Percent of firms formally registered when they started operations in Egypt:

In 2013 the survey referred to (88.7) percent for all countries, (87.0) percent for the Middle East \& North 
Africa and (91.6) percent for Egypt, and it has decreased slightly to (91.4) in 2016 Egypt.

Graph (2): The Percent of firms formally registered when they started Operations

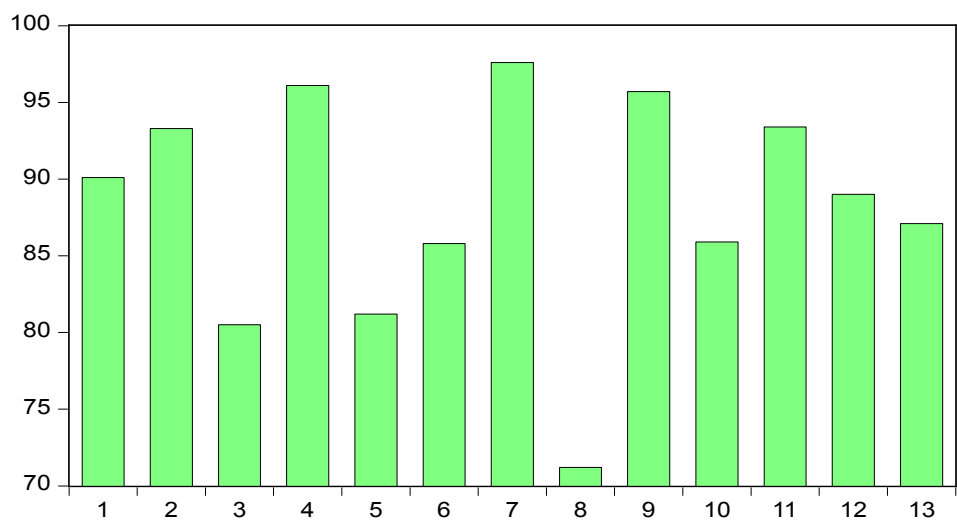

The source: the graph is done using Eviws 8 and the data of the World Bank survey 2013.

In 2016 the percent for small firms was (91.2), the percent for medium firms was (93.5) and the percent for large firms was (85.7). The highest percent was for (the $7^{\text {th }}$ column) Chemicals \& chemical products industry (97.6) and then (the $4^{\text {th }}$ column) Garments industry (96.1) and the least percent were for (the $8^{\text {th }}$ column) Rubber $\&$ plastics products industry.

3) The Percent of firms identifying practices of competitors in the informal sector as a major constraint: The survey results in 2013 referred to (28.3) percent for all countries, (27.7) percent for Middle East \& North Africa and (32.6) percent for Egypt. The 2016 survey mentioned that it was decreased for Egypt to be (22.7). 
Graph (3): The Percent of firms identifying practices of Competitors in the informal sector as a major constraint in Egypt in 2013 $\mathrm{p}$

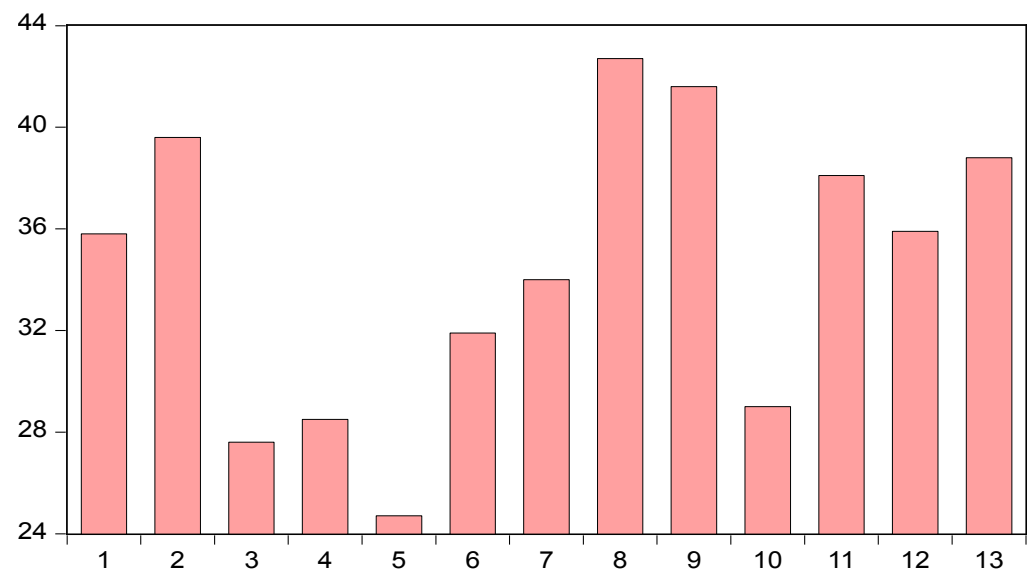

The source: the graph is done using Eviws 8 and the data of the World Bank survey 2013.

The highest percent was for (the $8^{\text {th }}$ column) Rubber $\&$ plastics products industry (42.7) and then (the $9^{\text {th }}$ column) Non Metallic minerals products industry (41.6).

4) The Percent of Firms identifying access to finance as a major constraint:

In 2013 the survey referred to (26.5) percent for all countries, (31.9) percent for Middle East \& North Africa and (28.5) percent for Egypt. The 2016 survey mentioned that it was decreased for Egypt to be (23.4).

Graph (4): Percent of Firms identifying access to finance as a major constraint

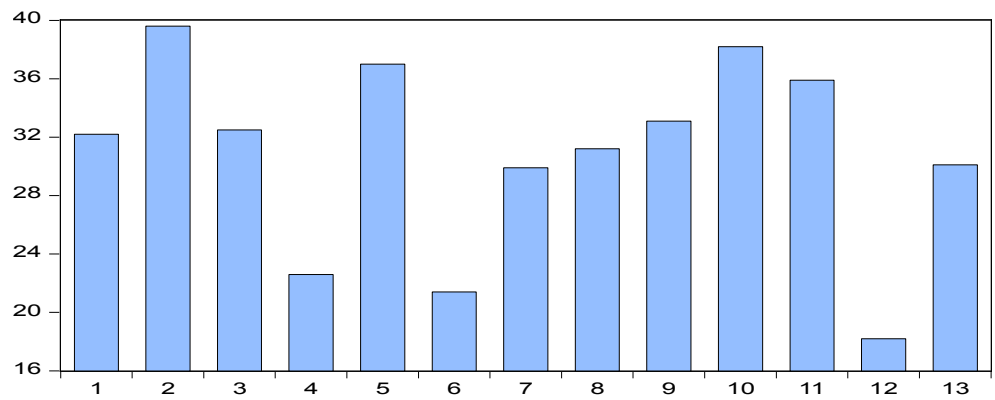

The source: the graph is done using Eviws 8 and the data of the World Bank. 
The highest percent was for (the $2^{\text {nd }}$ column) foods industry (39.6) and then (the $10^{\text {th }}$ column) the fabricated metal products industry (38.2) and the least percent was for (the $12^{\text {th }}$ column) the wood products industry. The percent of firms identifying that problem was (31.4) for small firms, (23.8) for medium, and (21.9) for large firms so; the Central Bank of Egypt (CBE) Initiative is a very important step to encourage the formalizing of the informal manufacturing sector entrepreneurs.

5) The Percent of firms identifying customs and trade regulations as a major constraint:

The survey in 2013 referred to (18.0) percent for all countries, (21.1) percent for Middle East \& North Africa and (8.8) percent for Egypt. The 2016 survey mentioned that it was increased for Egypt to be (20.1).

Graph (5): Percent of firms identifying customs and Trade regulations as a major constraint in 2013

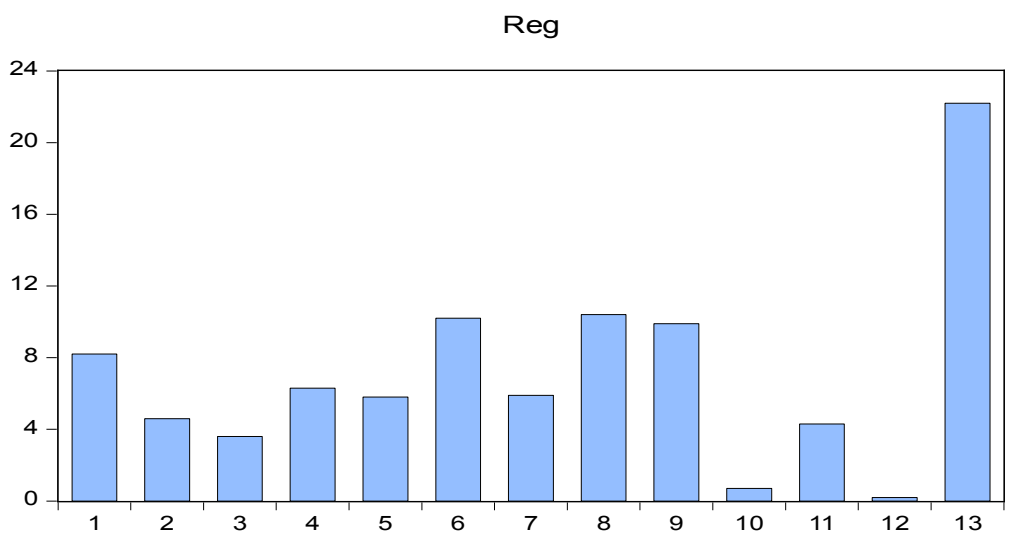

The source: the graph is done using Eviws 8 and the data of the World Bank.

The highest percent was for (the $13^{\text {th }}$ column) the other manufacturing industries (22.2) and then the rubber and 
plastics products industry (10.4) and the least percent was for (0.2) for the Wood products industry.

Meanwhile it may be richly for the analysis if the proportion of total inputs that are of foreign origin (\%) is mentioned here especially for the manufacturing industries as its highest percent was for Leather industry (53.4) and then the wood products industry (46.9). Moreover, the percent of firms using material inputs and/or supplies of foreign origin is very useful indicator here as it was (84.2) for leather industry and (76.4) for the Textiles industry.

6) The Percent of firms identifying tax rates as a major constraint: in 2013 the survey referred to (31.5) percent for all countries, (30.7) percent for Middle East \& North Africa and (20.4) percent for Egypt. The 2016 survey mentioned that it was increased for Egypt to be (47.8) percent.

Graph (6): The percent of firms identifying tax rates as a major constraint Tax Ra

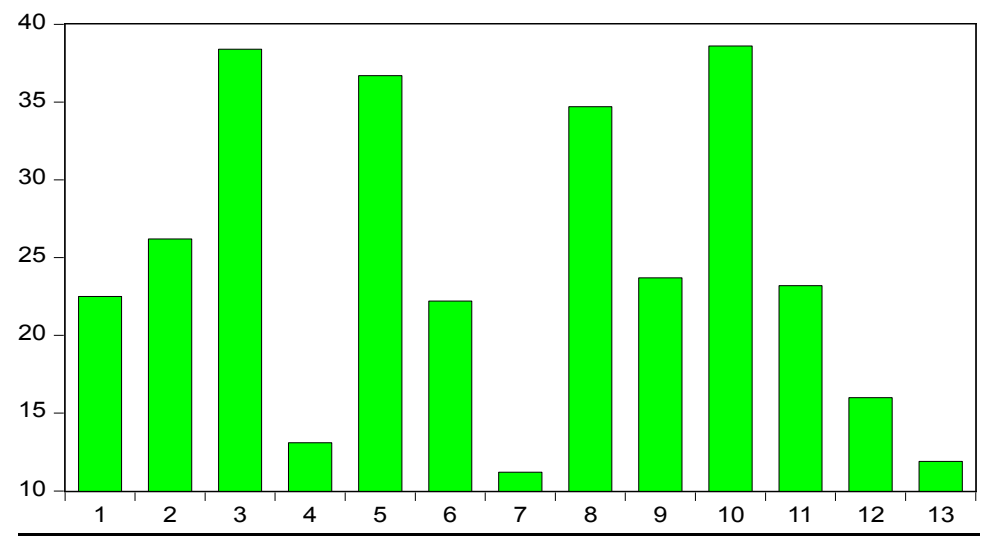

The source: the graph is done using Eviws 8 and the data of the World Bank survey 2013.

The highest percent was for (the $10^{\text {th }}$ column) the fabricated metal products industry (38.6) and then (the $3^{\text {rd }}$ column) the Textiles industry (38.4) and the least percent was for the Chemicals and chemical products (11.2). 
The percent of identifying that problem was for small firms (20.7), for medium (20.6) and for large firms (16).

7) The Percent of firms identifying tax administration as a major constraint: in 2013 the survey referred to (21.7) percent for all countries, (20.5) percent for Middle East \& North Africa and (14.9) percent for Egypt. The 2016 survey mentioned that it was increased for Egypt to be (29.4).

Graph (7): the percent of firms identifying Tax administration as a Major constraint

Tax Ad

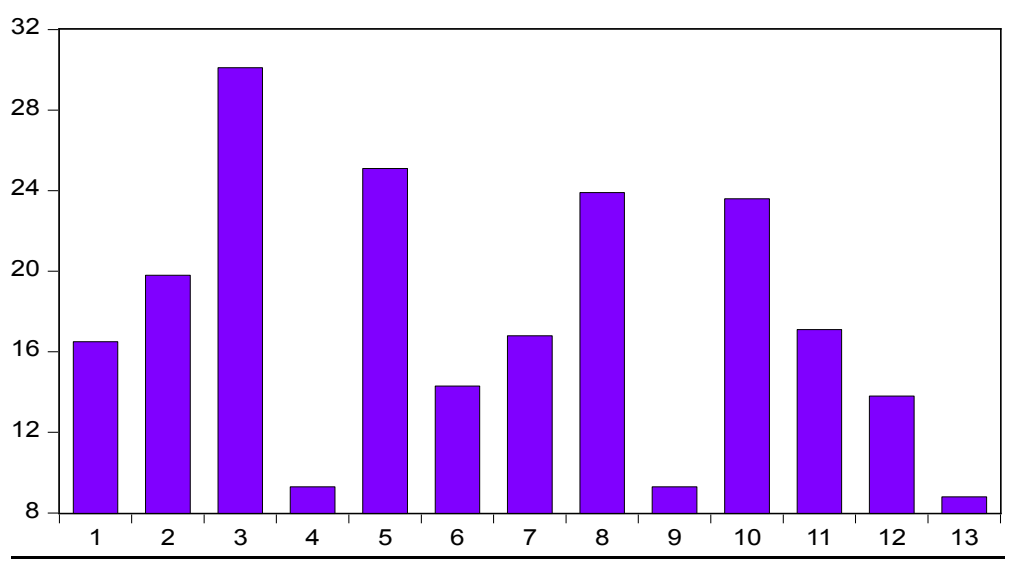

The source: the graph is done using Eviws 8 and the data of the World Bank survey 2013. The highest percent was for (the $3^{\text {rd }}$ column) the Textiles industry (30.1) and then (the $5^{\text {th }}$ column) the Leather Products industry (25.1). The percent of identifying that problem was for small firms (15), for medium (15.6) and for large (11).

8) The Percent of firms identifying business licensing and permits as a major Constraint: in 2013 the survey referred to the percent (13.7) for all countries, (18.4) for Middle East \& North Africa and (17.2) for Egypt. The 2016 survey mentioned that it was increased for Egypt to be (34.1). 


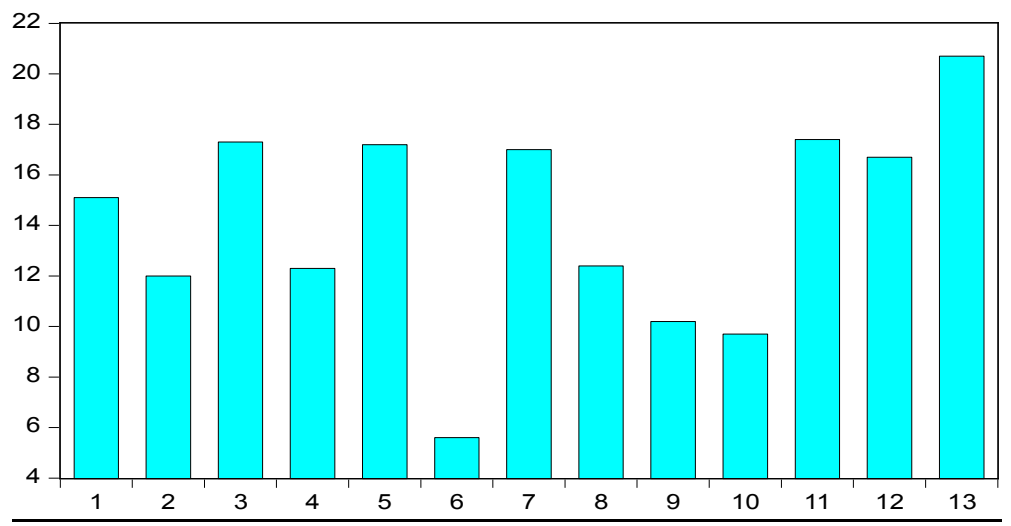

The source: the graph is done using Eviws 8 and the data of the World Bank survey2013.

The highest percent was for (the last column) the other manufacturing industries (20.7) and then (the $3^{\text {rd }}$ column) the Textiles industry (17.3). The small firms percent of identifying that was (16.8), the medium (17.9) and the large (17.5).

\section{5- The Model Specification and Estimation :}

The study assumes a bi-directional relationship between the informal sector and both of Taxes and Imports in Egypt, so the Regression analysis is not suitable here. According to the unit root test and co integration test the study may use VAR or VEC model.

The variables of the study are:
$\mathrm{I}=$ the Informal sector,
$\mathrm{T}=$ Taxes
$\mathrm{M}=$ Imports,
$\mathrm{R}=$ Inflation

The Inflation is included as the previous studies mentioned that there is a positive relation between inflation and the informal economy (Ercolani 2000).

The Informal manufacturing entrepreneurs' size is estimated here using the consumption of electricity index. It is calculated using the World Bank data base, assuming 
two fundamental assumptions; the first the year 1980 is the base year in calculations, the second; the greatest consumption of electricity in the informal economy is caused by the informal manufacturing sector, so the calculated value for the whole informal economy consumption of electricity is equal to the informal manufacturing sector consumption of electricity and is assumed to be a proxy for the manufacturing informal entrepreneurs.

\section{5-1- The Model Estimation and the Empirical Results:}

This part of the study is the empirical analysis of the relation between Imports, Taxes and Informal sector in Egypt (1980-2014).

The source of data is the World Bank, and the Informal sector data is calculated according to the Inputs approach (Electricity Consumption) which was used by ( Kaufmann and Klaipeda 1996) in their study with the World Bank and (Schneider 2000). The study here used the $3^{\text {rd }}$ scenario (Inefficiency in electricity consumption). The base year is 1980 for the index of Imports, Taxes and the calculation of the size of the informal sector.

The trend of the variables of the study is demonstrated in the appendix.

The taxes graph indicates the increasing trend during the period of the study, and the hyper increases were for the period (2000-2014).

The Imports graph indicates the increasing trend during the period of the study, and the hyper increases were for the period (2005-2014) as a result of the WTO agreements. The Informal sector graph indicates also the increasing trend but, the hyper increases started since 1986 and that may be a result for the Economic Reforms and Privatization.

\section{5-2- The unit root test:}

As the time series is 35 observations; the Augmented Dickey Fuller (ADF) test with constant and linear trend is 
used for the variables of the study to test the extent of stationary of data used.

Table (1): The unit root test (ADF)

\begin{tabular}{|c|c|c|c|}
\hline The variable & Level & $1^{\text {st }}$ Difference & $2^{\text {nd }}$ Difference \\
\hline $\mathrm{I}$ & -2.437 & $-7.794^{*}$ & \\
\hline $\mathrm{M}$ & -1.387 & $-4.776^{*}$ & \\
\hline $\mathrm{T}$ & 4.533 & -2.132 & $-5.275^{*}$ \\
\hline $\mathrm{R}$ & -2.978 & $-9.455^{*}$ & \\
\hline
\end{tabular}

(*) Significance is at the $1 \%$ level and the numbers are $\mathrm{T}$ values.

The lags interval $=8$

The (ADF) test indicates that no one of the variables is stationary at the level and both (I, M and R) are stationary at the $1^{\text {st }}$ difference while, Taxes variable is stationary at the $2^{\text {nd }}$ difference.

\section{5-3- The Co integration Test:}

The Johansen Co integration test is used to find weather there is a long run relationship among the variables or not, to decide the possibilities of using VAR or VEC estimation to test the hypothesis.

Table (2): The Co integration Test

\begin{tabular}{|c|c|c|c|c|}
\hline $\begin{array}{c}\text { Hypothesized } \\
\text { No. of CE(s) }\end{array}$ & Eigen value & $\begin{array}{c}\text { Trace } \\
\text { Statistics }\end{array}$ & $\begin{array}{c}0.05 \text { critical } \\
\text { value }\end{array}$ & Prob.** \\
\hline None* & 0.616 & 51.176 & 47.856 & 0.0236 \\
\hline At most 1 & 0.347 & 19.555 & 29.797 & 0.4535 \\
\hline At most 2 & 0.152 & 5.468 & 15.495 & 0.7572 \\
\hline $\begin{array}{c}\text { Hypothesized } \\
\text { No. of CE(s) }\end{array}$ & Eigen value & $\begin{array}{c}\text { Max-Eigen } \\
\text { Statistics }\end{array}$ & $\begin{array}{c}0.05 \text { critical } \\
\text { value }\end{array}$ & Prob.* $^{* *}$ \\
\hline None* & 0.616 & 31.621 & 27.584 & 0.0143 \\
\hline At most 1 & 0.347 & 14.087 & 21.132 & 0.3579 \\
\hline At most 2 & 0.152 & 5.453 & 14.265 & 0.6840 \\
\hline
\end{tabular}

Trace test indicates 1 co integrating eqn(s) at the 0.05 level

Max-Eigen value test indicates 1 co integration eqn(s) at the 0.05 level.

$\left.{ }^{*}\right)$ denotes rejection of the hypothesis at the 0.05 level.

(**) Mackinnon -Haug- Michelis (1999) p-values.

Lags interval (in first differences): 1 to 1 ; linear deterministic trend

Since the co integration test results indicated that there is a long-run relationship among the variables and the 
stationary requirements the Vector Error Correction Model is the suitable method of estimation.

\section{5-4- The Vector Error Correction Estimates ${ }^{37}$ :}

When the co integration test indicated that there is a longrun relationship among the variables of the study the suggested method is the VEC and the following table demonstrates the results of the estimation:

Table (3): VEC estimation the dependant variable is (D (log (I)))

\begin{tabular}{|l|l|l|l|}
\hline $\begin{array}{l}\text { Independent } \\
\text { variables }\end{array}$ & Coefficients & St. Error & T- Stat. \\
\hline $\mathrm{C}$ & 0.1936 & 0.0844 & $2.2925^{*}$ \\
\hline $\mathrm{D}(\log (\mathrm{I}(-1)))$ & 0.0173 & 0.2668 & 0.0649 \\
\hline $\mathrm{D}(\log (\mathrm{I}(-2)))$ & -0.2086 & 0.1753 & -1.1903 \\
\hline $\mathrm{D}(\log (\mathrm{M}(-1)))$ & -0.3829 & 0.4815 & -0.7954 \\
\hline $\mathrm{D}(\log (\mathrm{M}(-2)))$ & -0.0887 & 0.4347 & -0.2039 \\
\hline $\mathrm{D}(\log (\mathrm{T}(-1)))$ & 0.0371 & 0.2907 & 0.1276 \\
\hline $\mathrm{D}(\log (\mathrm{T}(-2)))$ & -0.3612 & 0.2762 & -1.3075 \\
\hline $\mathrm{D}(\log (\mathrm{R}(-1)))$ & 0.0016 & 0.1062 & 0.0154 \\
\hline $\mathrm{D}(\log (\mathrm{R}(-2)))$ & -0.0303 & 0.1025 & -0.2957 \\
\hline \multicolumn{1}{|c|}{$\mathrm{ECM}(-1)$} & -0.8816 & 0.3177 & $-2.7749 *$ \\
\hline $\mathrm{R}^{2}$ & 0.639 & Log Likelihood & 9.2019 \\
\hline Adj.R & 0.492 & \multicolumn{1}{|c|}{ Akaiki AIC } & 0.0499 \\
\hline Sum Sq. of Res. & 1.054 & Schwarz SC & 0.5079 \\
\hline S.E. equation & 0.219 & Mean Dependent & 0.0928 \\
\hline F.Stat. & 4.335 & S.D. Dependent & 0.3071 \\
\hline
\end{tabular}

The estimation result indicates that the $\operatorname{ECM}(-1)$ coefficient $=(-0.8816)$ in the Informal Sector equation, it is negative and significant which means that the elasticity of response is strong and about $88 \%$ of disequilibrium in the short-run is corrected in the long run by a relative change in Informal entrepreneurship. That means the existence of a long-run relationship between the independent variables and the Informal sector in Egypt during the period (1980-2014).

37 The Bayesian VAR was estimated as a try and the results indicates; $(\log T(-1))$ have a positive significant impact on Informal sector and ( $\log I(-1)$ and $\log M(-1)$ ) have positive significant impacts on Taxes.

The adj. $R^{2}$ for $(\log \mathrm{I})$ eq. $=0.92$ and for $(\log \mathrm{T})$ eq. $=0.98$ 
The ECM (-1) coefficient means that there was a negative long-run relationship between taxes, imports, inflation and informal sector in Egypt.

On the other hand, there was no short-run relationship, even though the only significance was for the constant with the value of $19 \%$ which refer to the response of the informal sector when the independent variables equal zero. The Granger causality test (lags $=2$ ) here indicates that Log (T) Granger cause Log (I) at the 1\% level. Also Log (I) Granger cause Log (M) at the 5\% level, finally Log (M) Granger cause Log (T) at the 5\% level.

The VEC estimation for the D ( $\log (\mathrm{M}))$ is not significant for both short-run and long- run so, the next VEC estimation analysis focus on Taxes.

Table (4): VEC estimation the dependant variable is $(D(\log (T)))$

\begin{tabular}{|l|l|l|l|}
\hline $\begin{array}{l}\text { Independent } \\
\text { Variables }\end{array}$ & Coefficients & St. Error & T- Stat. \\
\hline $\mathrm{C}$ & 0.0252 & 0.0656 & 0.384 \\
\hline $\mathrm{D}(\log (\mathrm{I}(-1)))$ & -0.5882 & 0.2075 & $-2.835^{*}$ \\
\hline $\mathrm{D}(\log (\mathrm{I}(-2)))$ & -.1724 & 0.1363 & -1.265 \\
\hline $\mathrm{D}(\log (\mathrm{M}(-1)))$ & -0.2632 & 0.3743 & -0.7033 \\
\hline $\mathrm{D}(\log (\mathrm{M}(-2)))$ & -0.1716 & 0.3379 & -0.5078 \\
\hline $\mathrm{D}(\log (\mathrm{T}(-1)))$ & 0.4281 & 0.226 & 1.8945 \\
\hline $\mathrm{D}(\log (\mathrm{T}(-2)))$ & 0.8451 & 0.2147 & $3.9355^{*}$ \\
\hline $\mathrm{D}(\log (\mathrm{R}(-1)))$ & 0.0463 & 0.0825 & 0.561 \\
\hline $\mathrm{D}(\log (\mathrm{R}(-2)))$ & -0.0792 & 0.0796 & -0.9946 \\
\hline $\mathrm{ECM}(-1)$ & 0.7431 & 0.2469 & 3.0085 \\
\hline $\mathrm{R}^{2}$ & 0.479 & Log Likelihood & 17.257 \\
\hline Adj.R ${ }^{2}$ & 0.266 & \multicolumn{1}{|c|}{ Akaiki AIC } & -0.4535 \\
\hline Sum Sq. of Res. & 0.170 & Schwarz SC & 0.0044 \\
\hline S.E. equation & 0.170 & Mean Dependent & 0.1899 \\
\hline F. Stat. & 2.254 & S.D. Dependent & 0.1987 \\
\hline & & \multicolumn{2}{|l}{} \\
\hline
\end{tabular}

The estimation result indicates that the ECM (-1) coefficient $=(0.7431)$ in the taxes equation, it is positive and significant which means that the elasticity of response is strong and about $74 \%$ of disequilibrium in the short-run 
is corrected in the long-run by a relative change in taxes. That means the existence of a long-run relationship between the independent variables and the taxes in Egypt during the period (1980-2014).

The ECM (-1) coefficient means that there was a positive long-run relationship between informal sector, imports, inflation and taxes. On the other hand, there was only one short run relationship between $(\mathrm{D}(\log (\mathrm{I}(-1))))$ and $(\mathrm{D}(\log (\mathrm{T})))$. The sign is negative which means that the elasticity of taxes in response to a change in informal sector by $(1 \%)$ is $(0.58 \%)$ in the inverse direction, the increase in informal sector by $1 \%$ leads to a decrease in taxes revenue by $0.58 \%$

The coefficients of the long run-relationship (correlation without causality) are significant for all variables with Informal sector and it is positive (0.49) for $(\log M(-1))$, negative (0.13) for $(\log \mathrm{R}(-1))$ and negative $(0.611)$ for $(\log$ $\mathrm{T}(-1))$. The expected for both Taxes and Inflation impact on Informality is positive.

It may be useful here to mention that the estimation result of the impact of taxes, imports and inflation on the informal manufacturing entrepreneurs as determinants; it was significant for both taxes and imports ${ }^{38}$.

\section{6- The Conclusion and Policy recommendation:}

This study used the fiscal approach for estimating the size and development of the informal sector for the period (1980-2014). The estimates depends on the calculated index values of informal sector (electricity consumption), taxes and imports, the base year is 1980 .

The result of the model estimation for the relationship between imports, taxes and informal sector was only

${ }^{38}$ For more details the determinants of the informal manufacturing entrepreneurs equation for Egypt, is submitted in the appendix 
significant for the long-run for informal economy equation and for taxes equation. The short-run significance also realized for these two variables. It means that imports are not a cause of informality and informality is not a cause for imports during the time period of study for Egypt.

In developing countries experts emphasized the importance of developing a favorable business environment as a precondition for formalization, but in Egypt that alone may not be sufficient. Efforts should be made to improve the capacity of entrepreneurs to meet the international standards and upgrade.

Improving the tax and import systems and credit availability may help to formalize the informal entrepreneurs in Egypt, but also the informal-formal linkages should be considered.

Clusters as units of policy intervention may permit the government to provide focused and specialized support to domestic entrepreneurs and this way of government intervention allowed generating possibilities for accessing new markets and acquiring new skills and becoming internationally competitive. 


\section{References:}

- $\quad$ Abdel Gawad G., (2003). "Measuring the macro economic effects of the hidden economy in Egypt", Unpublished Doctoral Dissertation, Helwan University, Egypt.

- Abdel-Mowla Somaya A.A., (2012). "The Egyptian tax system reforms, investment and tax evasion (2004-2008)", Journal of Economic Administrative Science, Vol. 28, No. 1, pp. 53-78.

- Ahumada Hildegart, Facundo Alvaredo and Alfredo Canavese, (2007). "The Monetary Method and the Size of Shadow Economy: A Critical Assessment", Review of Income and Wealth, Series 53, Number 2, June.

- $\quad$ Andrews, D., Aida Caldera Sánchez and Ăsa Johansson, (2011). " Towards a Better Understanding of the Informal Economy", $\underline{O E C D}$ Economics Department Working Papers, No. 873, OECD Publishing, Paris

- $\quad$ Araujo J. P. and Mauro Rodrigues, (2016). "Taxation, credit constrains and the informal economy", Economia, 17, pp. 43-55.

- Arvin-Rad Hassan and Maria Willumsen, (2010). " Economic Reform, informal-formal sector linkages and intervention in the informal sector in developing countries: A paradox", International Review of Economics and Finance, Vol. 19, Issue 4, October, pp. 662-670.

- Ayyagari Meghana, Asli Demirgüç-Kunt and Vojislav Maksmovic, (2008). Formal versus Informal Finance: Evidence from China", Policy Research Working paper, WPS4465, The World Bank.

- Bacchetta Marc, Ekkehard Ernst and Juana P.Bustamante, (2009). "Globalization and Informal Jobs in Developing Countries", WTO and ILO.

- Carr Marilyn and Martha Alter Chen, (2001). " Globalization and the Informal Economy: How Global Trade and Investment impact on the working poor", WIEGO.

- Charmes Jacques, (2012). " The Informal Economy Worldwide: Trends and Characteristics", the Journal of Applied Economic Research, vol. 6, no.2,pp. 103-132

- Chen Martha Alter, (2012). "The Informal Economy: Definitions, Theories and Policies", WIEGO Working Paper $\mathrm{N}^{\mathrm{o}} 1$, August.

- Fugazza Marco and Norbert Fiess, (2010). "Trade Liberalization and Informality: New stylized Facts", Policy Issues in International Trade and Commodities, Study series No. 43, UNCTAD.

- $\quad$ Galal Ahmed, (2005). "The Case for Formalization of Business in Egypt", Policy Viewpoint, ECES, the Egyptian Center for Economic Studies, September, p. 2.

- Gibson Bill, (2012). "Trade, Employment and the Informal sector: An agent-base analysis", The Journal of Applied Economic Research, No.6, pp. 277-310. 
- ILO, (2013). "Women and men in the informal economy: a statistical picture, $2^{\text {nd }}$ edition, pp. v-1

- ILO, (2017). "Way out of Informality: Facilitating Formalization of the Informal Economy in South Asia.

- ILO, (2018). "Women and men in the Informal Economy: a statistical picture, $3^{\text {rd }}$ edition, pp. v-1

- $\quad$ Kanbur R. and Michael Keen, (2015). "Reducing Informality", Finance and Development, the IMF, March, pp. 52-54.

- Kirzner Israel M. , (1999). " Creativity and/or Alertness: A Reconsideration of the Schumpeterian Entrepreneur", Review of Austrian Economics, No. 11, pp. 5-17

- $\quad$ Klarita Gërxhani, (2004). "The informal sector in developed and less developed countries: A literature survey", Public choice, 120, pp. 267300.

- McGee Robert W. and Michael Tyler, (2006). "Tax evasion and Ethics: a Demographic study of 33 countries", Andreas School of Business Working paper, Barry University, USA.

- $\quad$ Meagher Kate, (2013). "Unlocking the Informal Economy: A literature review on linkages between formal and informal economies in developing countries", WIEGO working paper No 27, April.

- Olofin Sam O.and Abiodun O. Folawewo, (2009). "Trade Reforms, Informal Sector Activity and Employment", A research discussion paper, joint WTO-ILO Workshop on Global Trade and Employment, 31 August-1 September 2009, Geneva, Switzerland.

- Ordòňez Jolio Cesarleal, (2014). " Tax collection, the informal sector, and productivity", Review of Economic Dynamics, Vol. 17, Issue 2, April, pp. 262-286.

- Puri Shivani and Tineke Ritzema, (2001). "Migrant Worker Remittances, Micro-finance and the Informal Economy: Prospects and Issues", Working Paper No.21, International Labour Office, International Labour Organization, Enterprise and Cooperative Development Department, Social Finance Unit.

- Ratnayake Ravi , (2016). " The role of trade in fostering Inclusive Growth in Asia-Pacific", in, Managing Globalization in the Asian Century, Editors; Hal Hill and Jayant Menon, ISEAS Publishing, Singapore.

- Schneider Friedrich, (2002). "Size and Measurement of the Informal Economy in 110 countries around the world, Australian National Tax Centre and World Bank.

- Siggel Eckhard, (2010). "The Indian informal sector: the impact of globalization and reform", International Labour Review, Vol. 149, No. 1, International Labour Organization.

- $\quad$ Sinba A., (2011). "Trade and the Informal Economy ",in Trade and Employment: From Myths to Facts, Editors: Marion Jansen, Ralf Peters and Jose Manuel Salazer-Xirinachs, ILO and EU. 
- $\quad$ Temple Jonathan and Ludger Wößmann, (2006). "Dualism and crosscountry growth regressions", Journal of Economic Growth, No. 11, pp. 187-228.

- Thai Mai Thi Thanh and Ekaterina Turkina, (2014). "Macro-level determinants of formal entrepreneurship versus informal entrepreneurship", Journal of Business Venturing, Vol. 29, Issue 4, July, pp. 490-510.

- Vollrath Dietrich, (2009). "The dual economy in long-run development", Journal of Economic Growth, No. 14, pp. 287-312.

- $\quad$ Webb J.W., R.D. Ireland and D.J. Ketchen, JR, (2014)." Toward a greater understanding of Entrepreneurship and strategy in the informal Economy", Strategic Entrepreneurship Journal, 8,pp 1-5

- Williams Colin C. and John Round, (2007). "Entrepreneurship and the Informal economy: A study of Ukraine's Hidden enterprise culture", Journal of Developmental Entrepreneurship, Vol. 12, No. 1, pp. 119136.

- Williams Colin C.and Sara Nadin , (2010). "Entrepreneurship and the Informal Economy: An Overview", Journal of Developmental Entrepreneurship, Vol. 15, No. 4, pp. 361-378. 


\section{Appendix:}

Graph (1): The Taxes index in Egypt (1980-2014)

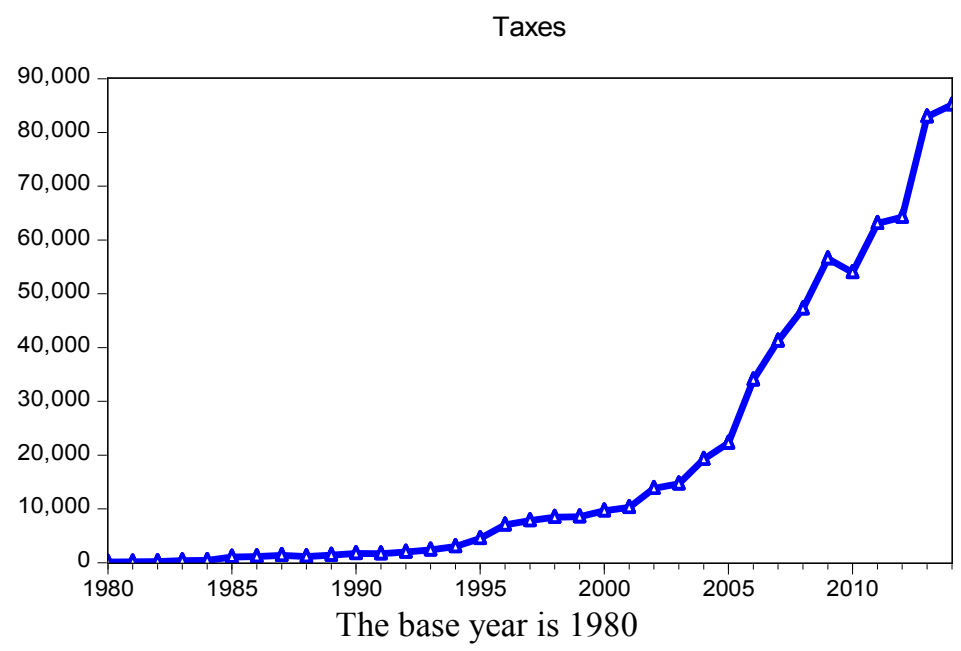

The source: The recent study has calculated the index using the

World Bank data and the graph is done using Eviews 8

Graph (10): The Informal sector and Imports in Egypt (1980-2014)

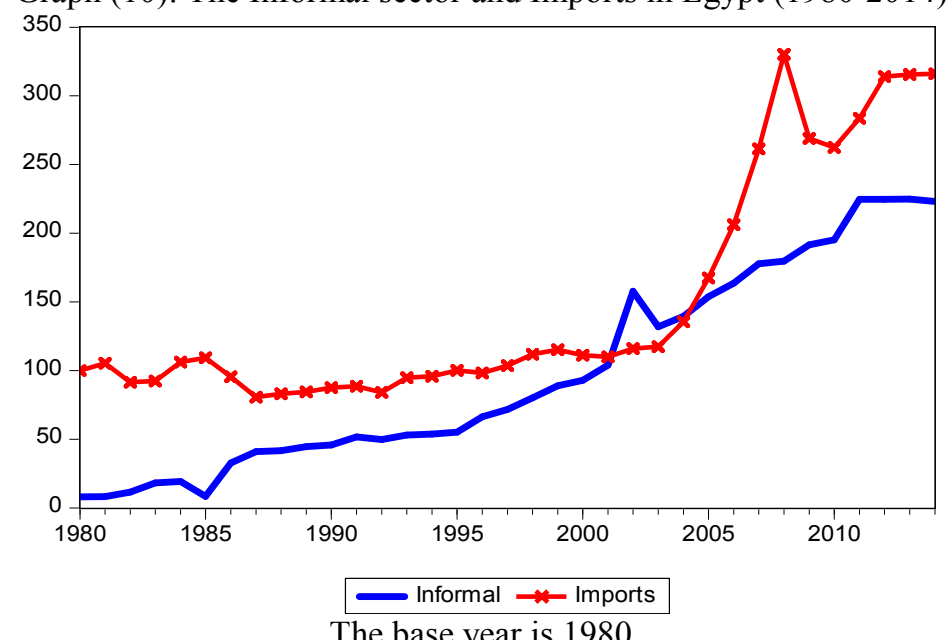

The source: The recent study has calculated the index using the

World Bank data and the graph is done using Eviews 8 
Dependent Variable: LOG(I)

Method: Least Squares

Date: 10/07/18 Time: 00:16

Sample: 19802014

Included observations: 35

\begin{tabular}{lrlrr}
\hline \hline \multicolumn{1}{c}{ Variable } & Coefficient & Std. Error & t-Statistic & Prob. \\
\hline \hline LOG(M) & -0.480827 & 0.171275 & -2.807340 & 0.0086 \\
LOG(T) & 0.612687 & 0.046679 & 13.12567 & 0.0000 \\
LOG(R) & 0.083309 & 0.081660 & 1.020196 & 0.3155 \\
C & 1.097824 & 0.526632 & 2.084616 & 0.0454 \\
\hline \hline R-squared & 0.943286 & Mean dependent var & 4.201519 \\
Adjusted R-squared & 0.937798 & S.D. dependent var & 1.012444 \\
S.E. of regression & 0.252507 & Akaike info criterion & 0.192453 \\
Sum squared resid & 1.976550 & Schwarz criterion & 0.370207 \\
Log likelihood & 0.632071 & Hannan-Quinn criter. & 0.253814 \\
F-statistic & 171.8687 & Durbin-Watson stat & 1.837453 \\
Prob(F-statistic) & 0.000000 & & \\
\hline \hline
\end{tabular}




\begin{tabular}{|c|c|c|c|}
\hline & Electricity & \multicolumn{2}{|c|}{ GDP per capita (constant LCU) } \\
\hline & & & \\
\hline 1980 & 375.1547 & 8770.504 & \\
\hline 1981 & 410.4917 & 8875.06 & \\
\hline 1982 & 449.7881 & 9509.708 & \\
\hline 1983 & 494.3002 & 9952.815 & \\
\hline 1984 & 512.0634 & 10283.73 & \\
\hline 1985 & 487.7404 & 10670.94 & \\
\hline 1986 & 578.7314 & 10655.64 & \\
\hline 1987 & 607.8254 & 10623.85 & \\
\hline 1988 & 621.7357 & 10883.24 & \\
\hline 1989 & 643.0495 & 11126.73 & \\
\hline 1990 & 662.7335 & 11473.19 & \\
\hline 1991 & 678.6277 & 11332.44 & \\
\hline 1992 & 682.3459 & 11581.75 & \\
\hline 1993 & 698.1408 & 11676.52 & \\
\hline 1994 & 710.6564 & 11903.43 & \\
\hline 1995 & 729.1917 & 12217.8 & \\
\hline 1996 & 786.9595 & 12586.49 & \\
\hline 1997 & 826.1236 & 13033.22 & \\
\hline 1998 & 869.8381 & 13312.38 & \\
\hline 1999 & 926.6078 & 13868.17 & \\
\hline 2000 & 961.9491 & 14345.19 & \\
\hline 2001 & 1013.254 & 14576.88 & \\
\hline 2002 & 1062.528 & 14642.19 & \\
\hline 2003 & 1128.721 & 14825.35 & \\
\hline 2004 & 1171.17 & 15145.11 & \\
\hline 2005 & 1241.343 & 15535.7 & \\
\hline 2006 & 1311.364 & 16307.2 & \\
\hline 2007 & 1401.192 & 17160.83 & \\
\hline 2008 & 1446.626 & 18067.34 & \\
\hline 2009 & 1512.459 & 18565.23 & \\
\hline 2010 & 1550.811 & 19139.2 & \\
\hline 2011 & 1658.964 & 19073.88 & \\
\hline 2012 & 1658.77 & 19071.15 & \\
\hline 2013 & 1658.593 & 19055.22 & \\
\hline 2014 & 1657.769 & 19182.56 & \\
\hline
\end{tabular}

